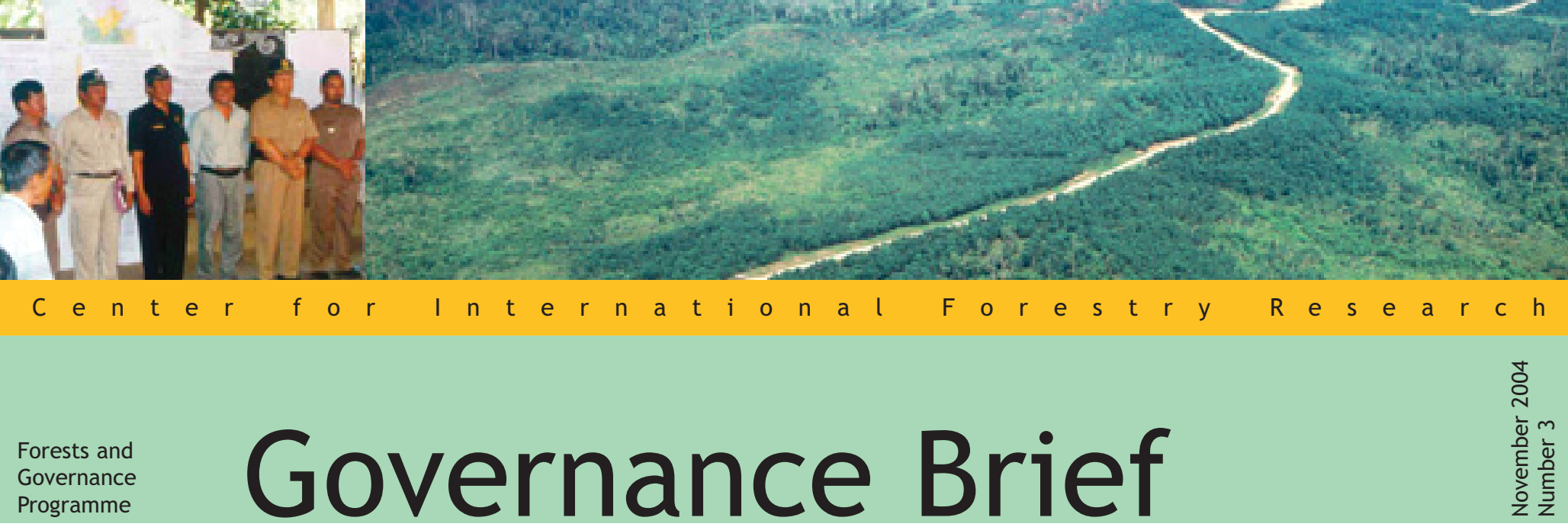

\title{
Sistem pengawasan terhadap penyelenggaraan pemerintah daerah kabupaten \\ Pembahasan Peraturan Perundangan di Bidang Pengawasan
}

\section{Ade Cahyat}

Poverty \& Decentralization Project

CIFOR (Center for International Forestry Research)-

BMZ (Bundesministerium für Wirtschaftliche Zusammenarbeit und Entwicklung)

E-mail: cahyat@cbn.net.id

\section{PENGANTAR}

Anggaran Pendapatan dan Belanja Negara (APBN) tahun anggaran 2003 berjumlah lebih dari 370 triliun rupiah. Sekitar 31\% atau lebih dari 116 triliun diantaranya adalah anggaran belanja daerah. Jumlah anggaran pemerintah daerah memang meningkat terus sejak desentralisasi. Sebagai contoh misalnya APBD Provinsi Kaltim pada tahun 1996/1997 hanya sekitar 139 milyar rupiah naik menjadi 913 milyar rupiah pada tahun 2002. Pengelolaan organisasi dengan dana sebesar ini tentunya memerlukan sebuah sistem pengawasan yang efektif.

Dalam sebuah organisasi, sistem pengawasan memegang peranan penting untuk memastikan bahwa segala sesuatunya berjalan sesuai dengan mandat, visi, misi, tujuan serta target-target organisasi. Sistem pengawasan memiliki dua tujuan utama yaitu akuntabilitas dan proses belajar.

Dari sisi akuntabilitas, sistem pengawasan akan memastikan bahwa dana pembangunan digunakan sesuai dengan etika dan aturan hukum dalam rangka memenuhi rasa keadilan. Dari sisi proses belajar, sistem pengawasan akan memberikan informasi tentang dampak dari program atau intervensi yang dilakukan, sehingga pengambil keputusan dapat belajar tentang bagaimana menciptakan program yang lebih efektif.

Tulisan ini bertujuan untuk membahas sistem pengawasan pemerintah daerah terutama pemerintah kabupaten berdasarkan peraturan perundangan yang berlaku di Indonesia.

\section{BENTUK PENGAWASAN}

Berdasarkan obyek pengawasan, kita dapat membagi pengawasan terhadap pemerintah kabupaten menjadi tiga jenis, yaitu pengawasan terhadap:

- Produk hukum dan kebijakan daerah

- Pelaksanaan penyelenggaraan pemerintahan daerah kabupaten serta produk hukum dan kebijakan

- Keuangan daerah

\section{PENGAWASAN PRODUK HUKUM DAN KEBIJAKAN}

Pengawasan terhadap produk hukum dan kebijakan dilakukan secara represif. Menurut PP N0. 20 Tahun 2001, Pengawasan Represif adalah pengawasan yang dilakukan terhadap kebijakan yang telah ditetapkan daerah baik berupa Peraturan Daerah, Keputusan Kepala Daerah, Keputusan Dewan Perwakilan Rakyat Daerah maupun Keputusan Pimpinan Dewan Perwakilan Rakyat Daerah dalam rangka penyelenggaraan Pemerintahan Daerah. Produk hukum dan kebijakan yang menjadi objek 


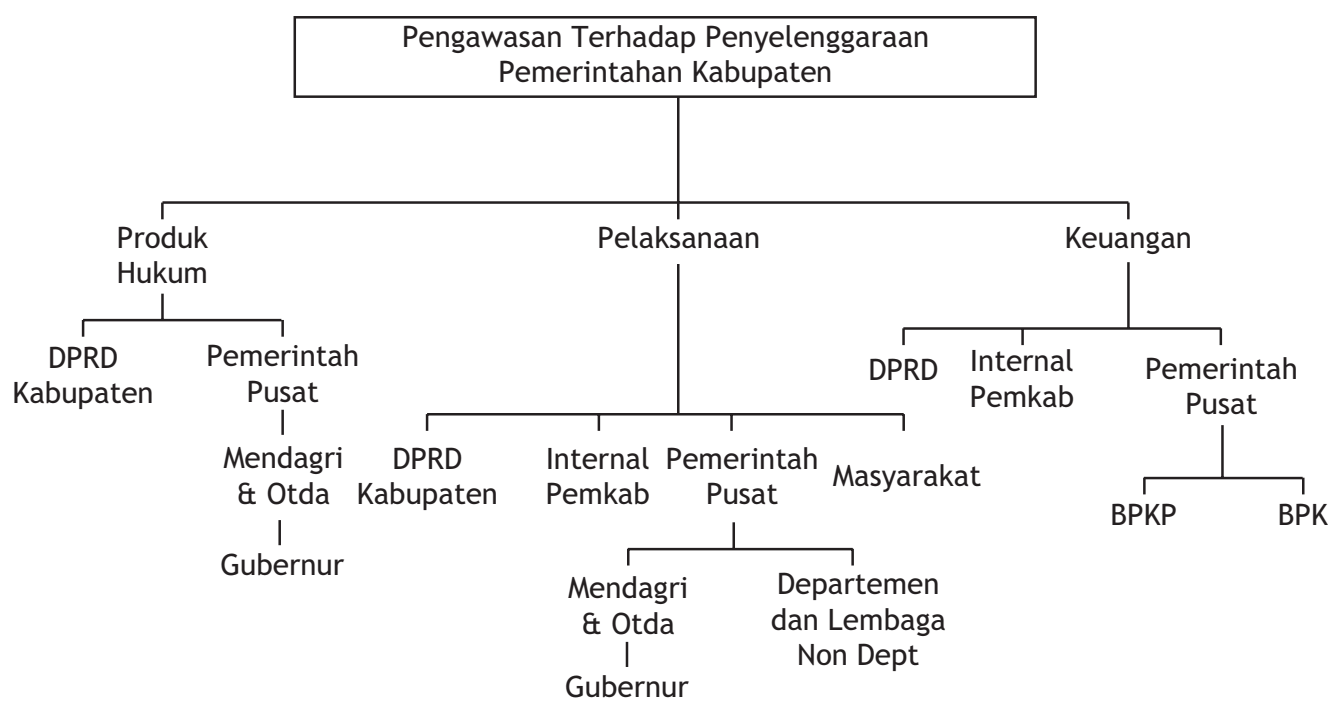

pengawasan adalah:

- Peraturan Daerah (Perda) Kabupaten

- Keputusan Bupati

- Keputusan DRPD Kabupaten

- Keputusan Pimpinan DPRD Kabupaten

Pihak yang dapat melakukan pengawasan terhadap produk hukum dan kebijakan kabupaten adalah:

- DPRD Kabupaten

- Menteri Dalam Negeri dan Otonomi Daerah (Mendagri \& Otda)

- Gubernur

\section{Pengawasan oleh DPRD kabupaten}

Kewenangan DPRD untuk mengawasi produk hukum hanya disebutkan di dalam Pasal 18 UU No. 22 Tahun 1999 tanpa dirinci lebih lanjut tentang batas kewenangan serta cara pengawasan.

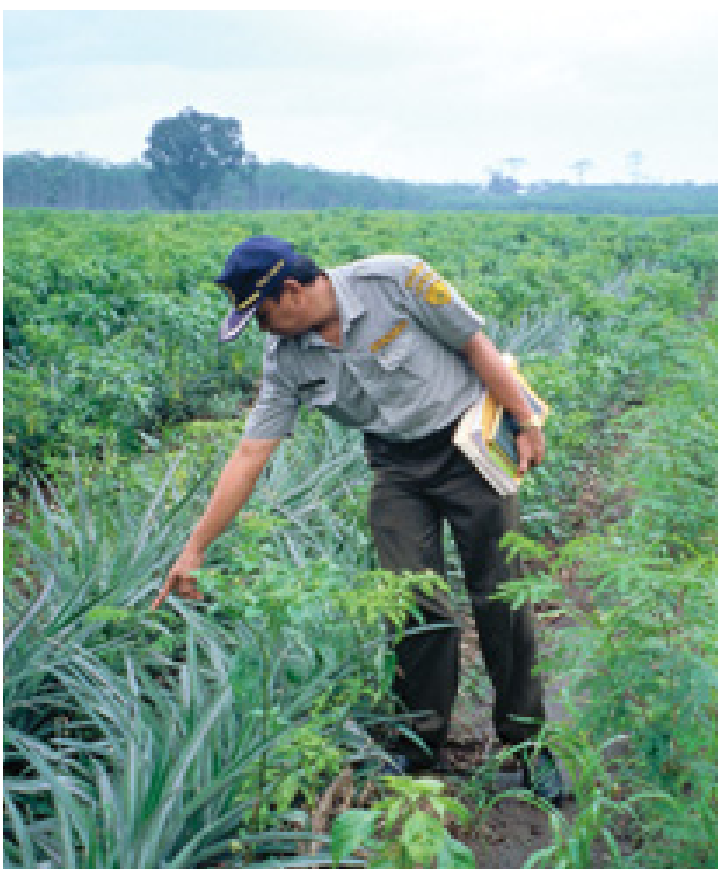

Pertanyaan kritis dalam bagian ini adalah: apakah DPRD memiliki kewenangan untuk membatalkan sebuah Surat Keputusan (SK) Bupati ketika SK Bupati tersebut tidak sejalan dengan Perda Kabupaten? Ternyata tidak ada satu peraturan perundangan yang menyatakan bahwa DPRD memiliki kewenangan untuk hal tersebut. Sehingga dapat disimpulkan bahwa pengawasan DPRD terhadap produk hukum dan kebijakan tidak disertai dengan kekuasaan penegakan (enforcement), misalnya melakukan pembatalan. Satu-satunya kekuatan DPRD dalam hal ini hanyalah meminta pertanggungjawaban Bupati dan mengusulkan pemberhentian Bupati kepada Presiden. Hal ini mungkin akan membuat pengawasan produk hukum dan kebijakan oleh DPRD Kabupaten menjadi kurang efektif.

\section{Pengawasan oleh pemerintah pusat}

Pemerintah pusat dalam hal ini Mendagri \& Otda dapat melaksanakan pengawasan terhadap produk hukum dan kebijakan secara represif yang dibantu oleh tim yang anggotanya terdiri dari unsur departemen atau lembaga pemerintah non departemen dan unsur lain sesuai dengan kebutuhan. Berbeda dengan pengawasan oleh DPRD Kabupaten, Mendagri \& Otda berhak membuat keputusan pembatalan atas Perda, SK Bupati, Keputusan DPRD dan Keputusan Pimpinan DPRD setelah melewati pemberian saran, pertimbangan, koreksi dan penyempurnaan.

Gubernur dapat melakukan pengawasan jika mendapatkan pelimpahan wewenang dari Mendagri \& Otda.

\section{PENGAWASAN PELAKSANAAN}

\section{Pengawasan oleh DPRD kabupaten}

Dalam hal pelaksanaan, DPRD Kabupaten 
memiliki kewenangan untuk melakukan pengawasan terhadap pelaksanaan:

- Peraturan Daerah

- SK Bupati

- Peraturan Perundangan Lainnya

- Kerjasama Internasional

Pengawasan tersebut dapat dilakukan dengan cara melakukan dengar pendapat, kunjungan kerja, pembentukan panitia khusus dan pembentukan panitia kerja yang dibentuk sesuai dengan peraturan tata tertib DPRD.

Untuk menjalankan fungsi pengawasan tersebut, DPRD dalam melaksanakan tugasnya berhak meminta pejabat negara, pejabat pemerintah, atau warga masyarakat untuk memberikan keterangan tentang suatu hal yang perlu ditangani demi kepentingan negara, bangsa, pemerintahan, dan pembangunan.

Pejabat negara, pejabat pemerintah, atau warga masyarakat yang menolak permintaan untuk memberikan keterangan dapat diancam dengan pidana kurungan paling lama satu tahun karena merendahkan martabat dan kehormatan DPRD. Dengan demikian, walaupun DPRD tidak memiliki kekuatan yang cukup untuk memberikan sanksi pada eksekutif, setidaknya DPRD memiliki kekuasaan yang cukup kuat untuk meminta keterangan dengan pihak-pihak yang sekiranya dapat memberikan masukan dalam rangka pelaksanaan fungsi pengawasan.

\section{Pengawasan internal pemerintah kabupaten}

Pengawasan internal pemerintah kabupaten secara keseluruhan merupakan tanggung jawab bupati. Cakupan pengawasan yang menjadi kewenangan kabupaten diatur di dalam Peraturan Daerah tentang Kewenangan Kabupaten. Pengawasan tersebut dilaksanakan oleh suatu Badan atau Lembaga Pengawas Kabupaten yang saat ini umumnya disebut Badan Pengawasan Daerah (Bawasda) Kabupaten.

Bawasda adalah lembaga teknis dan berfungsi sebagai unsur penunjang pemerintah kabupaten di bidang pengawasan. Bawasda Kabupaten dipimpin oleh seorang kepala badan yang merupakan pejabat eselon IIb, yang kedudukannya setingkat dengan asisten sekretaris daerah, Kepala Dinas dan pimpinan lembaga teknis lainnya (Kepala Badan dan Kepala Kantor). Kepala Bawasda bertanggung jawab kepada Bupati melalui Sekretaris Daerah.

Secara umum pengawasan internal pemerintah kabupaten mencakup:

- Penyelenggaraan pemerintah daerah

- Kinerja aparatur pemerintah kabupaten
Dalam pelaksanaannya peran Bawasda lebih banyak berfokus kepada pertanggungjawaban keuangan daripada pertanggungjawaban output. Perannya sangat mirip dengan peran auditor keuangan.

Dalam kasus di Kabupaten Kutai Barat, pengawasan terhadap output dari setiap proyek yang didanai oleh APBD dilaksanakan oleh beberapa kelompok kerja yang dibentuk oleh pemerintah kabupaten, yaitu:

- Kelompok kerja (pokja) monitoring yang dibentuk di setiap unit kerja yang bertugas untuk memonitor pelaksanaan proyek berdasarkan Daftar Anggaran Satuan Kerja (DASK). Hal ini sesuai dengan Keputusan Menteri Dalam Negeri dan Otonomi Daerah No. 50 tahun 2000

- Kelompok Kerja Fasilitasi (KKF) menjalankan fungsi monitoring dengan cara mengumpulkan dan menganalisis data dari pokja monitoring. Dalam pelaksanaanya, KKF banyak dijalankan oleh Bappeda. KKF dapat mengambil tindakan langsung jika ada penyimpangan ringan.

- Kelompok Kerja Pengendali (KKP) akan bekerja ketika ada penyimpangan berat. KKP diketuai oleh Wakil Bupati. KKP menyelenggarakan Rapat Koordinasi Pengendalian (Rakordal) yang dipimpin oleh Bupati.

Dengan demikian, pengawasan pelaksanaan hanya berfokus kepada output langsung dari proyek-proyek Pemda. Sekarang muncul pertanyaan, siapa yang mengawasi manfaat dan dampak dari proyek-proyek tersebut?, siapa pula yang mengawasi dampak dari peraturan perundangan dan kebijakan yang dikeluarkan oleh pemerintahan kabupaten?

Salah satu pengawasan terhadap manfaat dan dampak adalah pengawasan terhadap situasi kemiskinan. Peran ini dijalankan oleh suatu komite yang biasa disebut Komite Penanggulangan Kemiskinan (KPK). Sayangnya, KPK biasanya memiliki posisi yang lemah karena hanya dipimpin oleh seorang Kepala Dinas yaitu Kepala Dinas Pemberdayaan Masyarakat. Sehingga dalam pelaksanaannya, KPK sering hanya disibukan dengan program bantuan dan kurang bekerja untuk memberikan masukan pada kebijakan pembangunan. Dengan demikian, peran KPK dalam pengawasan manfaat dan dampak masih sangat lemah.

\section{Pengawasan oleh pemerintah pusat}

Pengawasan pelaksanaan oleh pemerintah pusat dibagi menjadi dua bagian:

- Pengawasan oleh Mendagri \& Otda 


\section{Kotak 1: Kewenangan Kabupaten Kutai Barat Dalam Bidang Pengawasan}

Berdasarkan Perda Kabupaten Kutai Barat No.2 Tahun 2001, kewenangan Pemerintah Kabupaten dalam bidang Pengawasan Fungsional adalah:

1. Penyusunan perencanaan pengawasan tahunan

2. Pelaksanaan rutin/reguler terhadap APBD Kabupaten Kutai Barat dan dana bantuan pembangunan kabupaten umum/khusus

3. Pelaksanaan pengawasan bidang pemerintahan umum, pertanahan, pemerintah daerah dan pemerintahan desa

4. Pelaksanaan pengawasan bidang sosial politik, ketertiban masyarakat, dan kesatuan bangsa

5. Pelaksanaan pengawasan bidang perekonomian daerah, pertanian, kehutanan dan perkebunan, perhubungan dan pariwisata serta industri pertambangan, koperasi, perdagangan dan lingkungan hidup

6. Pengawasan pelaksanaan bidang aparataur, pembinaan aparat dan administrasi kepegawaian

7. Pelaksanaan pengawasan bidang kesejahteraan, sosial, pendidikan/kebudayaan dan agama, kesehatan dan keluarga berencana, kependudukan, transmigrasi dan kesejahteraan masyarakat

8. Pelaksanaan pengawasan terhadap penerimaan pendapatan daerah dan Badan Usaha Daerah

9. Pelaksanaan pengawasan terhadap pengadaan barang/jasa serta pemeliharaan/penghapusan/penghapusan barang/jasa

10. Pelaksanaan pemeriksaan proyek-proyek fisik dan non fisik

11. Pelaksanaan pembangunan pengaduan masyarakat/kasus

12. Pelaksanaan pemeriksaan terpadu dalam rangka masa akhir jabatan kepala satuan kerja/camat

13. Pelaksanaan pemeriksaan terpadu dalam rangka masa akhir jabatan dinas/kantor dan badan

14. Pelaksanaan pemeriksaan terpadu sekretariat DPRD

15. Evaluasi tindak lanjut laporan hasil pemeriksaan aparat pengawasan fungsional pemerintah (APFP)

16. Inventarisasi dan penilaian penyelesaian bantuan ganti rugi

17. Inventarisasi dan identifikasi penggunaan ijazah palsu oleh PNS, aparat pemerintah daerah/desa

18. Inventarisasi dan memberikan rekomendasi atasan langsung/Pimpro dan Bendaharawan rutin/proyek

19. Penelitian dan penilaian laporan pajak-pajak pribadi (LP2P)

20. Menyusun rencana kebutuhan sarana penunjang kegiatan pengawasan

21. Pemeliharaan sarana dan prasarana pengawasan

22. Pengumpulan dan pengolahan data pengawasan

23. Inventarisasi peraturan perundang-undangan pengawasan pelaksanaannya

24. Menyiapkan bahan laporan pertanggungjawaban kepada daerah bidang pengawasan setiap akhir tahun anggaran

25. Menyiapkan bahan dan data dalam rangka pelimpahan penanganan kasus-kasus kepada kejaksaan

26. Menginventarisasi data dan membuat daftar PNS yang dikenakan hukuman disiplin

27. Melakukan pelatihan kantor sendiri (PKS) dalam rangka peningkatan mutu pengawasan

28. Penelitian dan penyelesaian terhadap kasus pelanggaran Peraturan Pemerintah No.10 tahun 1980 bersama juncto PP No.45 Tahun 1990

29. Mengagendakan surat masuk/keluar dan mendistribusikan sesuai disposisi pimpinan

30. Inventarisasi dan penelitian kekayaan pejabat di lingkungan Pemda

- Pengawasan oleh Menteri atau Pimpinan Lembaga Pemerintah Pusat Non Departemen

Pengawasan oleh Mendagri \& Otda mencakup pengawasan terhadap:

- Penyelenggaraan pemerintahan daerah

- Kinerja Otonomi Daerah

- Pelaksanaan tugas dekonsentrasi dan tugas pembantuan di bidangnya

- Efektivitas pelaksanaan pembinaan penyelenggaraan pemerintahan daerah sesuai bidang tugasnya

Pengawasan oleh Menteri atau Pimpinan Lembaga Pemerintah Pusat Non Departemen dilakukan di bawah koordinasi Mendagri \& Otda. Pengawasan tersebut mencakup pengawasan terhadap:

- Pelaksanaan tugas dekonsentrasi dan tugas pembantuan di bidangngnya
- Efektivitas pelaksanaan pembinaan penyelenggaraan pemerintahan daerah sesuai bidang tugasnya

Pengawasan oleh pemerintah pusat dapat dilaksanakan dengan cara:

- Pemeriksaan berkala, pemeriksaan insidentil maupun pemeriksaan terpadu

- Pengujian terhadap laporan berkala dan atau sewaktu-waktu dari unit/satuan kerja

- Pengusutan atas kebenaran laporan mengenai adanya indikasi terjadinya korupsi, kolusi dan nepotisme

- Penilaian atas manfaat dan keberhasilan kebijakan, pelaksanaan program, proyek serta kegiatan

Pemerintah pusat di bawah koordinasi Mendagri \& Otda dapat memberikan sanksi terhadap pemerintah kabupaten dan atau aparatnya yang 
menolak pelaksanaan serta tindak lanjut hasil pengawasan berdasarkan undang-undang.

Gubernur dapat melakukan pengawasan pelaksanaan terhadap pemerintah kabupaten jika mendapatkan pelimpahan wewenang dari pemerintah pusat. Instansi yang akan menjalankan tugas pengawasan adalah Badan Pengawasan Daerah (Bawasda) Provinsi.

Pengawasan pelaksanaan terhadap proyekproyek pembangunan oleh pemerintah pusat atau pemerintah provinsi umumnya terbatas kepada proyek-proyek yang didanai oleh APBN atau APBD Provinsi.

\section{Pengawasan oleh masyarakat}

Masyarakat memiliki hak untuk melakukan pengawasan terhadap penyelenggaraan pemerintahan daerah. Pelaksanaan pengawasan oleh masyarakat dapat dilakukan oleh masyarakat sebagai perorangan, kelompok maupun organisasi dengan cara:

- Pemberian informasi adanya indikasi terjadinya korupsi, kolusi atau nepotisme di lingkungan pemerintah daerah maupun DPRD.

- Penyampaian pendapat dan saran mengenai perbaikan, penyempurnaan baik preventif maupun represif atas masalah.

Informasi dan pendapat tersebut disampaikan kepada pejabat yang berwenang dan atau instansi yang terkait.

Menurut Pasal 16 Keppres No. 74 Tahun 2001, masyarakat berhak memperoleh informasi perkembangan penyelesaian masalah yang diadukan kepada pejabat yang berwenang. Pasal tersebut sebenarnya berusaha untuk memberikan kekuatan kepada masyarakat dalam menjalankan pengawasan.

Namun sayangnya tidak ada ketentuan tentang kewajiban pemerintah serta sanksi bagi instansi pemerintahan yang tidak menindaklanjuti informasi dan pendapat atau saran dari masyarakat. Dengan ketentuan seperti ini dapat dikatakan bahwa pengawasan oleh masyarakat sangat lemah dan sulit untuk dapat berjalan secara efektif.

\section{PENGAWASAN KEUANGAN}

\section{Pengawasan oleh DPRD kabupaten}

DPRD kabupaten memiliki kewenangan terhadap pengawasan pelaksanaan APBD sebagai pengawasan keuangan eksternal tingkat kabupaten. Seperti halnya pada pengawasan pelaksanaan, dalam pengawasan keuangan
DRPD kabupaten dalam melakukannya lewat dengar pendapat, kunjungan kerja, pembentukan panitia khusus dan pembentukan panitia kerja yang dibentuk sesuai dengan peraturan tata tertib DPRD.

Untuk memperkuat hak pengawasannya, DPRD dapat menolak pertanggungjawaban Bupati serta berhak untuk mengusulkan pemberhentian Bupati kepada Presiden.

\section{Pengawasan internal kabupaten}

Seperti halnya pada pengawasan pelaksanaan, Bawasda Kabupaten memiliki tugas pokok dan fungsi untuk melakukan pengawasan keuangan. Beberapa kewenangan kabupaten bidang pengawasan yang menyangkut pengawasan terhadap keuangan dan aset daerah adalah:

- Pelaksanaan APBD

- Penerimaan pendapatan daerah dan Badan Usaha Daerah

- Pengadaan Barang/Jasa serta Pemeliharaan/ Penghapusan Barang/Jasa

- Penelitian dan penilaian laporan pajakpajak pribadi

- Penyelesaian ganti rugi

- Inventarisasi dan penelitian kekayaan pejabat di lingkungan Pemda

Bawasda tidak dapat langsung memberikan sanksi baik sanksi administratif maupun sanksi pidana dan perdata. Oleh karena itu Bawasda dapat menyerahkan bukti-bukti temuan baik kepada bupati dan kepada aparat penegak hukum untuk ditindaklanjuti.

\section{Pengawasan oleh pemerintahan pusat}

\section{Badan Pengawasan Keuangan dan Pembangunan (BPKP)}

Badan Pengawasan Keuangan dan Pembangunan (BPKP) adalah lembaga pemerintah pusat non departemen yang dibentuk lewat Keppres No. 103 Tahun 2001. BPKP adalah perkembangan dari lembaga pengawas internal keuangan negara yang dibentuk sejak masa kolonial pada tahun 1936 lewat Djawatan Akuntansi Negara (Regering Accountants-Edienst). Informasi lebih lanjut tentang sejarah BPKP dapat dilihat pada website BPKP www.bpkp.go.id. BPKP adalah bagian dari Aparat Pengawasan Internal Pemerintah (APIP) seperti Inspektorat Jenderal (Irjen) di tingkat lembaga pemerintah pusat dan Bawasda (dulu Inspektorat Wilayah) di tingkat provinsi dan kabupaten.

Untuk menjalankan tugasnya BPKP memiliki perwakilan di tingkat provinsi. 
Dari peraturan perundangan yang ada, cakupan kewenangan BPKP tidak terlalu jelas. Ketidakjelasan ini ada pada pertanyaan apakah BPKP memiliki kewenangan untuk melakukan pengawasan pada APBD kabupaten atau sebenarnya hanya dalam lingkup keuangan daerah yang berhubungan dengan dana dekonsentrasi dan tugas pembantuan yang berasal dari APBN.

Dalam struktur BPKP memang ada satu posisi bernama Deputi Pengawasan Bidang Penyelenggaraan Keuangan Daerah, tapi tidak jelas apakah itu berarti termasuk keuangan daerah kabupaten, atau sebenarnya hanya tingkat provinsi karena pertanggungjawaban dana dekonsentrasi dan tugas pembantuan berada di tingkat provinsi. Yang sudah pasti bahwa BPKP bertugas untuk melakukan pengawasan penyelenggaraan APBN.

Untuk menjalankan tugas pengawasan BPKP dapat melakukan:

- audit keuangan

- investigasi

- evaluasi kinerja dan manajemen organisasi

Seperti halnya Bawasda Kabupaten, BPKP tidak dapat memberikan sanksi secara langsung. BPKP memberikan bukti-bukti temuan pengawasan keuangan kepada penegak hukum seperti jaksa dan kepolisian. BPKP juga dapat memberikan hasil temuannya kepada Badan Pemeriksa Keuangan (BPK). BPKP dalam menjalankan tugasnya bertanggung jawab langsung kepada Presiden.

\section{Badan Pemeriksa Keuangan (BPK)}

Badan Pemeriksa Keuangan (BPK) adalah salah satu lembaga tinggi negara yang kedudukannya sejajar dengan lembaga tinggi negara lainnya seperti Kepresidenan (Pemerintah), Dewan Perwakilan Rakyat (DPR), Mahkamah Agung dan Dewan Pertimbangan Agung (DPA). Dengan demikian BPK tidak dapat dipengaruhi oleh pemerintah. Informasi lebih lanjut tentang BPK dapat dilihat dalam situs www.bpk.go.id.

BPK menjalankan fungsi pengawasan keuangan eksternal, berbeda dengan BPKP yang melakukan pengawasan keuangan internal. Walaupun demikian, sering terdapat keluhan dari lembaga pemerintahan karena tumpang tindihnya pengawasan keuangan yang mengakibatkan pengawasan dilakukan lebih dari satu kali.

Berbeda dengan BPKP, BPK memiliki kewenangan untuk memeriksa seluruh keuangan negara termasuk APBN, APBD, BUMN dan BUMD.

Dalam menjalankan fungsinya, BPK melakukan pemeriksaan dokumen dan pemeriksaan setempat secara langsung. Pemeriksaan dokumen merupakan kegiatan utama yang dilaksanakan secara rutin dan terus menerus sepanjang tahun. Berdasarkan hasil pemeriksaan dokumen, pemeriksaan dapat dilanjutkan atau dilengkapi dengan pemeriksaan setempat. Hasil pemeriksaan BPK diserahkan kepada DPR, DPRD dan Dewan Perwakilan Daerah sesuai dengan kewenangannya.

\section{PERTANGGUNGJAWABAN KEPALA DAERAH}

PP No. 108 Tahun 2000 mengatur tentang tata cara pertanggungjawaban kepala daerah.

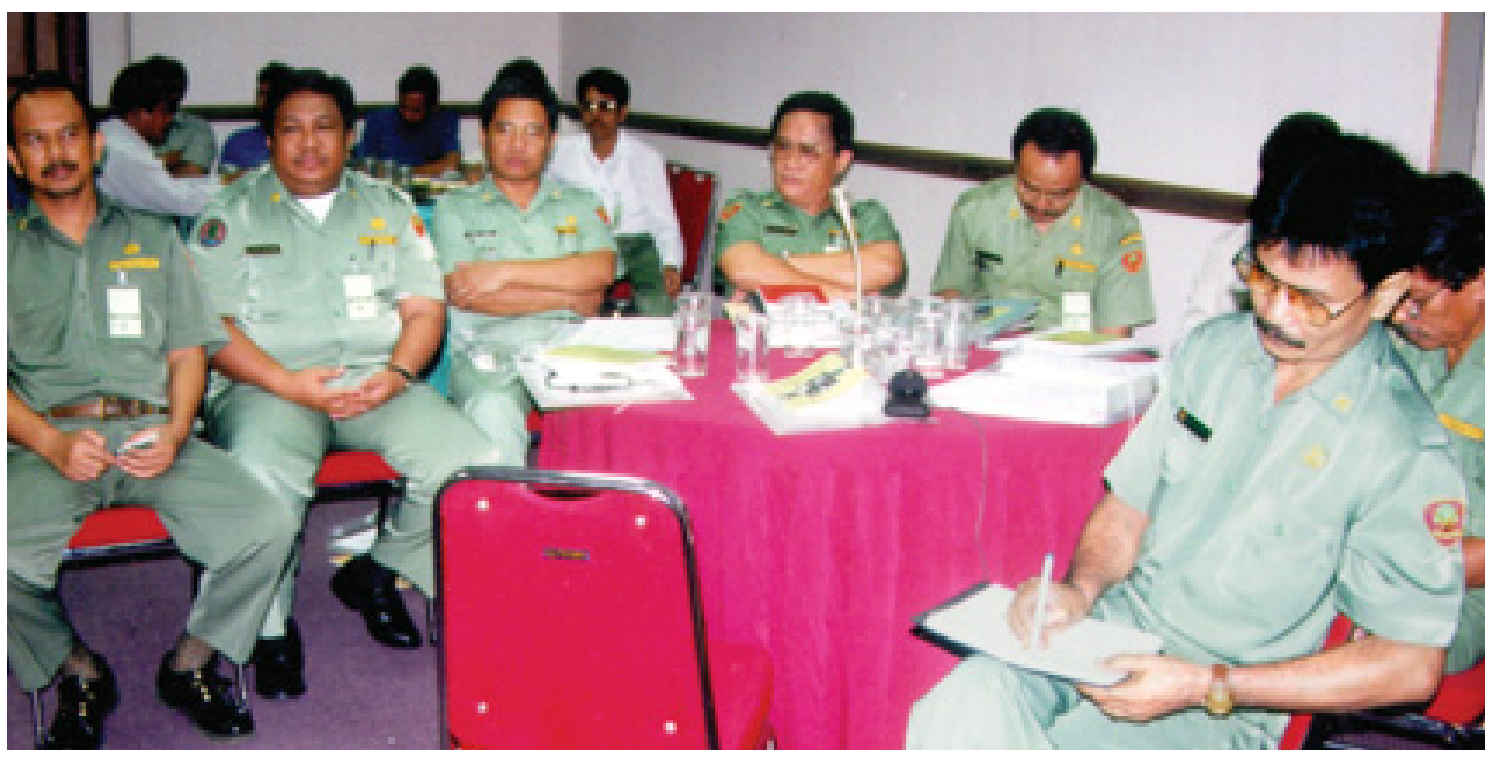


Bupati sebagai kepala daerah tingkat kabupaten bertanggung jawab kepada DPRD Kabupaten. Pertanggungjawaban Kepala Daerah terdiri dari:

- Pertanggungjawaban akhir tahun anggaran

- Pertanggungjawaban akhir masa jabatan

- Pertanggungjawaban untuk hal tertentu

Pertanggungjawaban yang dilakukan adalah atas:

- Penyelenggaraan pemerintahan

- Perbuatan pribadi yang diduga mengandung unsur tindak pidana

Dalam hal pertanggungjawaban atas penyelenggaraan pemerintahan dilakukan berdasarkan tolok ukur pada dokumen rencana strategis daerah (Renstra).

Pertanggungjawaban Kepala Daerah kepada DPRD atas penyelenggaraan pemerintahan merupakan pertanggungjawaban pelaksanaan APBD dalam bentuk perhitungan APBD berikut penilaian kinerja berdasarkan tolok ukur Renstra.

Dengan demikian pertanggungjawaban kepala daerah tentang penyelenggaraan pemerintahan dituntut untuk dapat menggambarkan dua hal utama yaitu penggunaan APBD dan kinerja pembangunan. Penilaian kinerja pembangunan dilaksanakan dengan mengacu kepada dokumen perencanaan daerah.

\section{KESIMPULAN}

Model-model pengawasan terhadap pemerintah daerah sangat berorientasi kepada akuntabilitas. Sementara pengawasan dengan tujuan sebagai proses belajar masih sangat lemah, padahal tujuan pengawasan sebagai proses belajar merupakan hal penting bagi organisasi yang ingin berkembang berdasarkan belajar dari pengalaman (learning based organisation).

Dari sisi proses, pengawasan hanya berfokus kepada pengawasan indikator input dan output dan sangat lemah pada pengawasan indikator manfaat dan dampak. Padahal dalam sistem anggaran satuan kerja, Pemda dituntut untuk juga melakukan pengawasan terhadap indikator manfaat dan dampak.

Mendagri \& Otda adalah pihak yang paling kuat dalam melaksanakan pengawasan pemerintahan kabupaten, terutama untuk pengawasan produk hukum dan pelaksanaan penyelenggaraan pemerintahan kabupaten. Walaupun DPRD memiliki kewenangan untuk melakukan seluruh jenis pengawasan, kedudukan DPRD yang sejajar dengan Bupati (Pemerintah Kabupaten) membuat DPRD tidak memiliki kekuatan yang cukup dalam memberikan sanksi.

Bawasda Kabupaten adalah instansi penting dalam bidang pengawasan internal, baik pengawasan keuangan maupun pengawasan pelaksanaan. Namun kedudukannya yang setara dengan dinas serta badan di Kabupaten membuat lembaga ini tidak memiliki kekuatan yang cukup dalam melakukan pengawasan.

Peran pemerintah provinsi dalam melakukan pengawasan di tingkat kabupaten hanya mungkin jika mendapat pelimpahan wewenang dari pemerintah pusat atau untuk proyekproyek dengan dana dari APBD Provinsi.

Walaupun masyarakat memang memiliki hak untuk melakukan pengawasan, namun tidak ada ketentuan yang dapat memperkuat posisi masyarakat sehingga sangat sulit untuk membuat pengawasan masyarakat dapat berjalan efektif.

Dari uraian di atas, dapat disimpulkan bahwa kekuatan pengawasan pemerintah kabupaten masih berada di tingkat pemerintah pusat. Potensi untuk belajar dari pengawas perlu ditingkatkan di kabupaten.

\section{REKOMENDASI}

1. Pemerintah daerah perlu untuk menciptakan sistem pengawasan terhadap manfaat dan dampak dari pembangunan. Salah satu pengawasan manfaat dan dampak yang penting adalah pengawasan terhadap situasi kemiskinan atau kesejahteraan masyarakat. Hal ini juga penting untuk dapat memenuhi sistem pengelolaan keuangan baru yang berbasiskan pada kinerja.

2. Mengingat kuatnya peran Menteri Dalam Negeri (Mendagri) dalam pengawasan pemerintahan daerah, maka sangat perlu untuk menciptakan mekanisme check and balance untuk mengimbangi kekuasaan tersebut.

Kekuasaan Mendagri yang sangat kuat seringkali membuat mekanisme demokrasi di daerah menjadi lemah. Hal ini dapat dilihat pada kasus kemelut di Pemerintah Provinsi Kalimantan Selatan dan Provinsi Bali.

3. Perlu dipertimbangkan untuk menciptakan sistem yang lebih adil dan transparan untuk 
mekanisme resolusi konflik antara peraturan perundangan daerah dengan peraturan perundangan pemerintah pusat. Jika memungkinkan, Mahkamah Konstitusi dapat memiliki tugas tambahan untuk menjalankan fungsi tersebut.

\section{LAMPIRAN}

Daftar peraturan perundangan yang dikaji:

(1) Undang-Undang Dasar Negara Republik Indonesia Tahun 1945

(2) UU No. 5 Tahun 1973 tentang Badan Pemeriksa Keuangan

(3) UU No. 22 Tahun 1999 tentang Pemerintahan Daerah

(4) UU No. 25 Tahun 1999 tentang Perimbangan Keuangan antara Pemerintah Pusat dan Daerah

(5) UU No. 29 Tahun 2002 tentang Anggaran Pendapatan dan Belanja Negara Tahun Anggaran 2003

(6) UU No. 24 Tahun 2003 tentang Mahkamah Konstitusi

(7) PP No. 25 Tahun 2000 tentang Kewenangan Pemerintah dan Kewenangan Provinsi Sebagai Daerah Otonom.

(8) PP No. 84 Tahun 2000 tentang Pedoman Organisasi Perangkat Daerah

(9) PP No. 105 Tahun 2000 tentang Pengelolaan dan Pertanggungjawaban Keuangan Daerah

(10) PP No. 106 Tahun 2000 Pengelolaan Pertanggungjawaban Keuangan Dalam Pelaksanaan Dekonsentrasi dan Tugas Pembantuan

(11) PP No. 108 Tahun 2000 Tata Cara Pertanggungjawaban Kepala Daerah

(12) PP No. 20 Tahun 2001 tentang Pembinaan dan Pengawasan Penyelenggaraan Pemerintahan Daerah
(13) Keppres No. 74 Tahun 2001 tentang Tata Cara Pengawasan Penyelenggaraan Pemerintahan Daerah

(14) Keppres No. 103 Tahun 2001 tentang Kedudukan, Tugas, Fungsi, Kewenangan, Susunan Organisasi, dan Tata Kerja Lembaga Pemerintah Non Departemen.

(15) Keppres No. 46 Tahun 2002 tentang Perubahan Keppres No. 103 Tahun 2001.

(16) SK Mendagri \& Otda No. 50 Tahun 2000 tentang Pedoman Susunan Organisasi dan Tata Kerja Perangkat Daerah Kabupaten/Kota

(17) Perda Kutai Barat No. 2 Tahun 2001 tentang Kewenangan Kabupaten

(18) Perda Kutai Barat No. 6 Tahun 2001 tentang Pembentukan Organisasi dan Tata Kerja Badan Pengawasan Kabupaten Kutai Barat

Daftar situs internet yang dikunjungi:

(1) GTZ-SFDM www.gtzsfdm.or.id

(2) Badan Pemeriksa Keuangan dan Pembangunan www.bpkp.go.id

(3) Direktorat Jenderal Perimbangan Keuangan Pusat Daerah-Departemen Keuangan: www.djpkpd.go.id

(4) Badan Pemeriksa Keuangan www.bpk.go.id

(5) Central for Local Government Inovation www.clgi.or.id

(6) Lembaga Informasi Nasional www.lin.or.id

(7) Departemen Keuangan www.depkeu.go.id

(8) Departemen Dalam Negeri dan Otonomi Daerah www.depdagri.go.id

(9) Sekretariat Negara www.ri.go.id

(10) Koran Kompas www.kompas.com

(11) Liputan 6 SCTV www.liputan6.com

(12) Kaltim Post www.kaltimpost.web.id

(13) Pemerintah Provinsi Kaltim www.kaltim.go.id

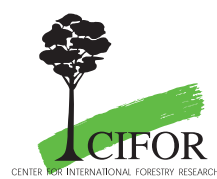

